\title{
How migrants manifest their transnational identity through online social networks: comparative findings from a case of Koreans in Germany
}

Sunyoung Park ${ }^{1 *}$ and Lasse Gerrits ${ }^{2}$

\author{
* Correspondence: sunyoung.park@ \\ uni-bamberg.de \\ ${ }^{1}$ Bamberg Graduate School of Social \\ Sciences, Otto-Friedrich University \\ Bamberg, Bamberg, Germany \\ Full list of author information is \\ available at the end of the article
}

\begin{abstract}
Although migration has long been an imperative topic in social sciences, there are still needs of study on migrants' unique and dynamic transnational identity, which heavily influences the social integration in the host society. In Online Social Network (OSN), where the contemporary migrants actively communicate and share their stories the most, different challenges against migrants' belonging and identity and how they cope or reconcile may evidently exist. This paper aims to scrutinise how migrants are manifesting their belonging and identity via different technological types of online social networks, to understand the relations between online social networks and migrants' multi-faceted transnational identity. The research introduces a comparative case study on an online social movement led by Koreans in Germany via their online communities, triggered by a German TV advertisement considered as stereotyping East Asians given by white supremacy's point of view. Starting with virtual ethnography on three OSNs representing each of internet generations (Web $1.0 \sim$ Web 3.0), two-step Qualitative Data Analysis is carried out to examine how Korean migrants manifest their belonging and identity via their views on "who we are" and "who are others". The analysis reveals how Korean migrants' transnational identities differ by their expectation on the audience and the members in each online social network, which indicates that the distinctive features of the online platform may encourage or discourage them in shaping transnational identity as a group identity. The paper concludes with the two main emphases: first, current OSNs comprising different generational technologies play a significant role in understanding the migrants' dynamic social values, and particularly, transnational identities. Second, the dynamics of migrants' transnational identity engages diverse social and situational contexts. (keywords: transnational identity, migrants' online social networks, stereotyping migrants, technological evolution of online social network).
\end{abstract}

(c) The Author(s). 2021 Open Access This article is licensed under a Creative Commons Attribution 4.0 International License, which permits use, sharing, adaptation, distribution and reproduction in any medium or format, as long as you give appropriate credit to the original author(s) and the source, provide a link to the Creative Commons licence, and indicate if changes were made. The images or other third party material in this article are included in the article's Creative Commons licence, unless indicated otherwise in a credit line to the material. If material is not included in the article's Creative Commons licence and your intended use is not permitted by statutory regulation or exceeds the permitted use, you will need to obtain permission directly from the copyright holder. To view a copy of this licence, visit http://creativecommons.org/licenses/by/4.0/. 


\section{Introduction}

\section{Problem statements}

In migration studies, "transnationalism" has long been a widely used concept to explain the globalised social phenomenon taking place beyond the nation-state border (Vertovec 2007, 2009; Blommaert 2013). Given the contemporary migration has become more complex and multidirectional, migrants' transnational identity tends to be much more dynamic and individually contextualised. The recent term 'superdiversity' describes very well such contemporary migrants as “... multiple-origin, transnationally connected, socio-economically differentiated and legally stratified immigrants who have arrived over the last decade" (Vertovec 2007). However, in the real-life of migrants, their identity still tends to be seen through the classical border-based frames given by the country of origin, host country, or quite often, by ethnicity. Taking a closer look into the everyday lives of immigrants in destination society, migrants face numerous challenges extended by those existing frames and strive to settle and shape their own identity in the way they can cope with the society where they (hope to) belong (Grzymala-Kazlowska 2016). In this process, migrants not only reflect their desires but also agree with the given views from the people in destination society (Blommaert and Varis 2011). The migrants who just landed in the new world often face the challenges against their identity for the first time in such a process, realising the gap between their own definition of 'who I am' and the 'others' judgement of 'who you are'. The fundamental reasons of such conflicts are mainly from the narrow and conflated understanding of migrants' background through the typical images formed by 'others', who are the majority groups of the host society (Sarangi 1996, p. 7; Vieten 2014).

A diverse and unique shape of identity places in the core of many relevant social issues in any society where migrant communities exist. Most of the migrants' communities nowadays emerge on Online Social Network [OSN] s, where like-minded people can easily gather and share their values, thoughts and feelings without limitation of the physical space (Castells 2004; Wellman 2005; Scheepers et al. 2014). Therefore, OSN, as a core mean of communication amongst migrants, may reflect the up-to-date dynamics of migrants' identity the most. This paper investigates how a migrant group can manifest their transnational identity in diverse ways by looking at a recent social issue alleged by a group of South Koreans in Germany via an online petition, which catalysed them to express their feelings of belonging, especially concerning the stereotyped image of East Asian migrants in Germany. ${ }^{1}$

\section{A controversial advertisement}

In late February 2019, a German retail chain Hornbach released its commercial on television and online media in German-speaking countries to promote its Do-ItYourself shops. The commercial quickly became viral but not for the advertisement itself. Instead, its main message led a South Korean doctoral student in Germany

\footnotetext{
${ }^{1}$ South Koreans in Germany are the largest Korean immigrant group in Europe and third largest East Asian migrants in Germany next to those from China and Vietnam, comprising approximately 45 thousands of people (Ministry of Foreign Affairs, Republic of Korea 2019). Over 77\% of them are highly educated, including digital literacy, which allows them to actively utilise OSNs in their everyday social lives more than the other groups (Bertelsmann 2018).
} 
to start an international petition ${ }^{2}$ that gained much attention in a short period. The petition claimed that the advertisement was discriminatory in the way it pitched white men versus a woman of East Asian descent. ${ }^{3}$ The advertisement's message was ambiguous, and the petition starter expressed dismay with the implied stereotypes of East Asian women for the company's primary target group of white men engaging in DIY activities. The petition fired up the East Asian migrants in Germany to organise a social movement via different OSN channels, following the manner of the contemporary hybrid movement such as \#metoo campaign ${ }^{4}$ (Caren et al. 2020). Given the \#metoo was to accuse the different degrees of sexism that women have had to bear in their lives, this movement - with own hashtag \#ich_ wurde_geHornbacht (meaning, "I was (offended) by Hornbach" in German) - has centred on the subtle racism against East Asian people in Europe. People have actively shared their experiences with the stereotyped and conflated prejudice of Germans (mostly indicating white men) to East Asian women, which implies the sexual objectification of any women who have young East Asian appearances. This brings again how the misjudgment of 'others' in host society may affect the immigrants feeling of belonging. Koreans in Germany, who already have negative personal experiences due to the unified prejudice against 'East Asian', would feel offended as the woman in the scene may address anyone with the similitude of her ethnic appearance.

The movement quickly gained much traction in the German, Korean and other international press, as well as South Korean migrant communities in many European countries including Germany. The issue provoked the migrants to share their thoughts and experiences in their OSNs, related to the advertisement but also more broadly about the experience and the stereotypes one encounters when establishing a living as an (East) Asian migrant in Germany. On top of that, some of the community members started channelling the online dynamics into online and offline social movements, including street demonstrations in Berlin and Seoul, an online counter-campaign with videos and posters, and releasing a public statement sent to the Embassy of the Republic of Korea in Germany and relevant German government officials. Consequently, the German Communication and Media Committee (Werberat) decided to ban the commercial, giving the following reasons for the ban: "degrading and discriminating against a certain group of people". These stipulate that people in commercial advertising should not discriminate against "on the basis of their gender, their origin, their race, their language (...)".

The advert's withdrawal was the demanded outcome, but the level of activities in various OSNs remained high even after the ban. Indeed, such favourable outcome

\footnotetext{
${ }^{2}$ On the online petition website "change.org": https://www.change.org/p/wolfgang-rupf-wir-stehen-gegen-dasrassistische-und-frauenverachtende-unternehmen-hornbach

${ }^{3}$ The sequence of scenes first showed a couple of bulky men in a pastoral scenery doing manual labour, and their sweaty cloths are collected and packed by two scientists - whose appearances seem like a white man and an Asian man. In the next scene, an East Asian-looking woman buys one such package from an automatic vending machine and proceeds to smell its contents, with a close-up of her face showing her being extremely aroused. A text superimposed on the image of the woman reads "the smell of spring".

${ }^{4}$ The "Me Too" campaign created one exemplary way of the participatory online social movement, proving that a specific social issue going viral in online may exert significant influence on the individuals' online behaviour to share their relevant experiences and thoughts in their online social networks (Juris et al. 2012; Margetts et al. 2015; Roth-cohen et al. 2019).
} 
catalysed the participants to talk more about their daily experiences until around the end of May 2019, when the momentum gradually lowered. The participants became less emotional than before but more determined, mainly sharing messages about how they have been protecting their rights as migrants in Germany and combating the discrimination they encounter. Over 3 months, the social event went through five different phases, four of which similar to the ones identified by Polletta and James (2001), and an additional fifth phase defined as the aftermath by authors (see Fig. 1).

Given the issue cuts to the heart of the discrimination of a certain migrant group's identity, it is vital to scrutinise the narratives shared amongst the party concerned to understand "behind the scene", rather than only looking at the movement itself. The ethnographic approach allows the researchers to gain deeper insights into how people interpret and act on the situation they face (Hammersley and Atkinson 2007; Hammersley 2015). Thus, we have deployed virtual ethnography (Hine 2008; Boellstorff et al. 2012), focusing on the narratives in different OSNs, the most popularly used by Korean migrants in Germany. We have observed how the migrants share their ideas and feelings with other members and how they constitute their own way of belonging in the host society (see also Schrooten 2012).

The debates particularly played out over different types of OSNs. On the one hand, a Facebook group featured an extended discussion about the feeling of being offended by the depiction of East Asians in the commercial and an urgent need to speak up to enhance the social awareness in Germany. On the other hand, one of the largest membership-only web communities questioned the necessity of the movement and featured discussions as to whether the reaction from Korean migrants was overly sensitive in the face of a German culture those Koreans may have misunderstood. It became more evident that members in the various OSNs would describe themselves in different ways - ranging as "traditional Korean", "Korean-German", "Asian", and "minority in the migrant society in Germany". Such descriptions appear to inform the posters' views on the contested commercial and to drive the narratives among the members in each OSN.

Those different types of OSN respectively represent different stages in the development of the internet, broadly classified as Web 1.0, Web 2.0 and Web 3.0 (O'Reilly 2007; Vickery and Wunsch-Vincent 2007). It seems that the types of OSN coincide with different expressions of the transnational identity of Koreans in Germany, which may imply a relationship between the type of technology and platform and the ways transnational identity is formed. However, the relationship between (manifestations of) transnational identity and technology has not received much scholarly attention. Using the case as pars pro toto, we continuously investigate the narratives in three OSNs of which respectively represent each of different internet generations, with a focus on the following research question:

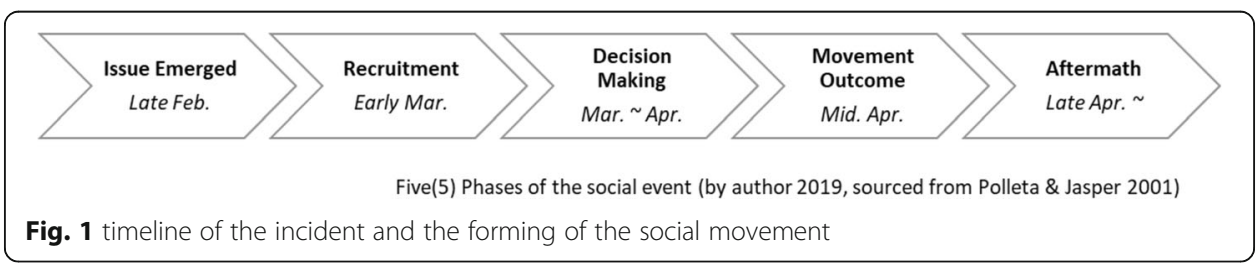


"How do Korean migrants differentiate the manifestation of their transnational identity by type of OSNs, and what factors explain these differences?"

The focus lies on a) what kind of identities are manifested in each OSN, b) what are the different features among the OSNs and c) how do these features influence the expression of certain types of identity.

We analysed the data with two-step Qualitative Data Analysis, which juxtapose the results with the characteristics of different generations of OSNs (Flick 2014). The first step was Qualitative Content Analysis, inductively coded the texts from the postings to examine the associations between different OSNs and the postings manifesting the members' thoughts and feelings on the event (Elo \& Kyngäs 2008; Schreier 2012). The second step with Thematic Analysis (Boyatzis 1998) was carried out with a hybrid approach between inductive and deductive coding. Based on the descriptive codes from the first step, we developed interpretive codes to embrace the profound understanding of the posters' intentions that eventually steer to the relationship between transnational identity manifested and different types of OSNs. In the following sections, we firstly discuss those different generations of OSN and relate them how migrants' transnational identities may emerge from such networks. Next, we discuss the research method deployed in the empirical part and report the findings. The final part of the article discusses the implications of the findings vis-à-vis existing literature.

\section{Online social network and migrants' transnational identity Nature and evolution of migrants' online social network}

To begin with, we distinguish the difference between the definition of network and community in the article. Network refers to the web of individual relationships and connections comprising of nodes and links amongst members, and that networks may construct communities with the people having a shared identity or interest around the topic that represents the collective intention (Sonn and Fisher 1996). In the early stage of migration process, migrants tend to develop dense networks to acquire relevant information and familiarise themselves in the host society. Yet, those networks tend to be temporal as constantly reshaped and modified in the latter stages (Boyd 1989, as cited in Ryan 2011). Researchers who observe the dynamics of migrants' networking and joining/creating the communities convince that the migrant, who have accessibility to the OSNs, tend to engage in the community concerning of own interests, not a shared ethnicity or country of origin like a past (Gill and Bialski 2011; Vieten 2014). This temporality is associated with the Granovetter's notion of "weak ties", which highlights the dynamics of alienations to shared information for an individual's desire to integrate into the society (Granovetter 1983).

Prior researches distinguish a difference in the strength of the migrants' social ties between online and offline networks (Cornelius et al. 2009; Komito \& Bates 2011; Boyd and Ellison 2007; Postill 2008). While offline relationships are characterised as strong ties, the relationships situated online are constituted as weak ties. Accordingly, online social networks should be understood as being composed of more instantaneous, light and diverse relationships, in line with the proliferation of 'network individualism' (Wellman 2001; Castells 2011). Network individualism signifies the shift of unit of 
community from 'group' to 'individual', which coincides with the transformation of OSNs. Unlike the classical model of community as group-based, tightly knit, and emphasising the group identity as a whole, the community on network individualism focuses on the connected individuals, sharing and accepting more diverse identities. Accordingly, the community on network individualism is more fragmented and often reshaping their network schemes with other individuals on different occasions (Feenberg and Bakardjieva 2016; Postill 2008). The current research is important for the interaction between the technology and its users in expressing their transnational identities. We differentiate between two mechanisms: (1) manifestation of transnational identity as the result of matching expectations with the characteristics of the three generations of OSNs; (2) mediation as the process of negotiating a transnational identity according to prevailing social norms on each generation of OSN.

If OSN fosters online ties, it also concerns the shaping and persistence of social networks of migrants in host countries (Nedelcu 2012; Oiarzabal 2013; Dekker \& Engbersen 2014). OSN enables migrants to develop their social capital, namely by improving their livelihoods, mobilising assets, and defending themselves against social discrimination. At the individual level, the exchange of information and the formation of relationships of trust are the building blocks of migration networks (Castells 2011; Chen and Choi 2011; Castles and Miller 2009; Lingel et al. 2014). An important aspect is that the social network can be created and recreated regardless of physical locations and borders. In transcending the connection with migrants' offline networks, the online platform allows migrants to create more dynamic social networks according to their choice of time, space, people, and purpose (Wellman 2001; Castells 2011; Dolata 2013). In this context, online space can play a role as a buffer zone for isolation and/or integration in the destination society (Lim et al. 2016).

There has been accumulating evidence that the change of community space is linked to the emergence of OSN, given a reciprocal relationship between the structure of the OSN and that of community (Scheepers et al. 2014). OSN often highlights the core characteristics of an online community, including its identity, in the sense that the communication among the members is based on texts and pictures which leave explicit evidence to assure the identity (cf. Komito \& Bates 2011). While there is no doubt that technology has transformative power (Dolata 2013; Yearley 2014), this capacity is not inherent to the artefact but rests on society's interaction with it (Bijker 1997; 2010). This perspective frames technology as a configuration of material artefacts and social practices. It implies that different social groups will read technology and interact with it in different ways, culminating in different practices (Pinch \& Bijker 1984; Sismondo 2004). It goes for technology at large, and online, digital technologies in particular (Fuchs 2008). The structure and dynamics of social networks that play out in digital space need to be understood as an enactment of that configuration.

As the internet has evolved in general, so have the OSN that have emerged online communities out of like-minded individuals meeting online. Early types are characterised by closed memberships of the community that allowed members to build a guarded sphere that offered the opportunity of establishing persistent and private relationships between members. In such type of environment, namely Web 1.0, the online communities are severed so that it is hard for the people outside of the community to find and join. Came the 2000s; a change emerged with a more open and interactive 
form of OSN since then termed Web 2.0 to differentiate it from the closed nature of the original OSN. People build more flexible and diverse networks on global social platforms such as Facebook, which still give the room to develop the private community but with greater openness to the people outside than before. More recently, the openness and participatory nature of OSN has extended considerably to provide users with a customised, semantic web. The relationship becomes more instant and temporal, and people tend to link themselves with the others on the same interest of the moment, rather than sticking in the fixed community for a long time. It has then become more widely known as Web 3.0 (Blank and Reisdorf 2012; Aghaei 2012). Although all OSN run on the same digital infrastructure, there are distinct differences between the various generations, as summarised in Table 1 . The differences matter because they may coincide with different types of migrants, the different ways in which they express themselves, and how they would prefer to relate to others in their networks and communities. The most significant differences between OSNs include the audience (accessibility of the messages), how easy it is to find and join the community from the outside, and the cohesion of the community, i.e., how tightly bound the members are. The latter is the proverbial 'glue' that holds the community together.

\section{Migrants' transnational identity}

In this section, we shed light on the transnational identity per se and relate the stereotyping issue in the host society. Echoing Vertovec's "Superdiversity" as a concept of contemporary migrants' identity, this paper uses the term 'transnational' to capture migrants' unique sense of belonging that can be individually contextualised and diversified beyond the nation-state borders (Vertovec 2007; Blommaert and Varis 2011). There is confrontation between the norms and values that shape the identity in the home society and those prevalent in the host society, which nudges migrants to be constantly aware of who they are and how they (re) present themselves in various situations. They will also become more acutely aware of how others (mainly in the destination society) perceive them and which societal position they are believed to belong (Waldinger 2015). Such pressures drive the generation of transnational identities in various ways, including as assimilating, isolating, integrating, or binary being in (or beyond) home and destination society (Glick-Schiller 2003; Castles and Miller 2009; Vertovec 2015; Waldinger 2015). The newly formed identity is not necessarily a trade-off with the original identity. A migrant may simultaneously experience a strong sense of belonging to

Table 1 Different generations of Online Social Networks and their main characteristics

\begin{tabular}{|c|c|c|c|}
\hline & Web 1.0 & Web 2.0 & Web 3.0 \\
\hline $\begin{array}{l}\text { Platform } \\
\text { type }\end{array}$ & $\begin{array}{l}\text { Membership-based } \\
\text { websites/blogs }\end{array}$ & $\begin{array}{l}\text { Group communities among the members } \\
\text { of widespread global portals and social } \\
\text { media }\end{array}$ & Global social media \\
\hline $\begin{array}{l}\text { Message } \\
\text { style }\end{array}$ & $\begin{array}{l}\text { Long, descriptive, } \\
\text { written style of } \\
\text { language }\end{array}$ & $\begin{array}{l}\text { Mid-to Long, relatively concise, mixed style } \\
\text { of written/spoken language }\end{array}$ & $\begin{array}{l}\text { Short, abstracted, usually } \\
\text { spoken/informal style of } \\
\text { language }\end{array}$ \\
\hline Audience & $\begin{array}{l}\text { Focused members in } \\
\text { the closed group }\end{array}$ & Members and some related users & open to public \\
\hline Accessibility & Restricted & Somewhat restricted & Unrestricted \\
\hline
\end{tabular}


the home society, a sense of assimilation in the host society, and the transnationalism 'across the borders' (Sheringham 2010; Tamaki 2011).

Stereotyping minor ethnicities in the host society is not a new issue in migration studies. Till the early 2000s, it has been mainly discussed in the Northern American contexts where the migrants' endemic identity has been confronted by white supremacy throughout their modern migration history. Sarangi observes how the conflation of the cultural stereotyping of Asian migrants in the United States affects those Asians' sense of belonging (Sarangi 1996). Such a social norm can also create internal gaps of the belonging between early generations and later generations in the same migrant group. Pyke and Dang's case study gives an example of how the migrants who just landed in the host society - so-called 'Fresh-Of-the-Boat' - are likely to have conflicts with the earlier generation of migrants who already have formed own way of assimilated identity, so-called 'whitewashed', much reflecting the images given by "others" (Pyke \& Dang 2003). While those 'Fresh-Of-the-Boats' are engaging with people from a similar background (country, religion, profession, among others) to learn the social norms and behaviours, they also realise how such stereotyped prejudice may affect their positions in the host society. They find the like-minded people who may feel the same agony, share every days' thoughts and feelings, and re-establish their own social ties. In this way, migrants may speak up for empowering themselves against certain discriminatory events that counteract their desires of belonging, by developing new communities that centre on shared identities. Naturally, online communities are constantly active. A particular incident, such as the one triggered by the ad mentioned earlier, elicits migrants' positions, stances, ties, emotions and feelings about being an alien in the host society. Consequently, such an incident provide the researcher with a casus pars pro toto through which migrants' various dynamics of transnational identity can be mapped and analysed.

\section{Qualitative data analysis}

As discussed earlier, this research's virtual ethnography focuses on the narrative development of Koreans in Germany as taking place in three types of OSNs across the five phases of the event, as shown in the introduction to this paper (see Fig. 1). The three OSNs included as the cases are: a website A representing Web 1.0, a Facebook group B representing Web 2.0, and Twitter representing Web 3.0., ${ }^{5}$ particularly with the messages written by the users giving the clues of their geographical heritage as Koreans. With Twitter being almost entirely open to the entire public (except for direct messages), there were no specific steps required to collect data. For A and B, we asked the administrator for anonymised use of their data. Data was collected from postings and subsequent discussion threads (replies), and tweets (in the case of Twitter) about the topic. The data sources are listed in Table 2.

The relevant postings from each OSN were imported to NVivo 12 for the two-step qualitative data analysis ${ }^{6}$ : the first step taken is inductively developing the codes for

\footnotetext{
${ }^{5}$ The exact names of the sample groups A and B can be easily tracked by searching certain keywords on the internet, therefore they are anonymised here. This was also pre-requisite for getting permission to use their data for this research

${ }^{6}$ By virtue of understanding Korean, English and German, it was possible to read and code most of the texts collected.
} 
Table 2 Data sources and main features of the discussions on each generation of Online Social Network

\begin{tabular}{llll}
\hline & $\begin{array}{l}\text { Web 1.0 } \\
\text { (Website A) }\end{array}$ & $\begin{array}{l}\text { Web 2.0 } \\
\text { (B Facebook group) }\end{array}$ & $\begin{array}{l}\text { Web 3.0 } \\
\text { (Postings in Twitter) }\end{array}$ \\
\hline Group Size & $\begin{array}{l}21,200 \sim 21,300 \\
\text { members }\end{array}$ & (approx.) 41,220 members & Uncountable \\
$\begin{array}{l}\text { number of } \\
\text { postings analysed } \\
\begin{array}{l}\text { Language of } \\
\text { postings }\end{array}\end{array}$ & $\begin{array}{l}\text { Korean } \\
\text { Mostly in Korean, some in English or }\end{array}$ & $\begin{array}{l}\text { Korean (approx. 60\%), English } \\
(30 \%), \text { German (10\%) }\end{array}$ \\
\hline
\end{tabular}

each case according to Qualitative Content Analysis, aiming to identify the overarching associations among data (Schreier 2012). The second step was interpreting the descriptive codes from the first step to code the patterns, ${ }^{7}$ which can succinctly interpret the aspects of the findings, following Thematic Analysis (Boyatzis 1998). From here, the researchers actively used memos to summarise the coding units from the existing codes to build the code hierarchy which at the end, clustered into three themes as highest parent codes called "Tones of voice", "Expected Audience" and "Group Identity manifested" (see Table 3).

\section{Qualitative content analysis}

As mentioned above, the unit of analysis encompassed all messages containing meaningful information and pointers regarding the properties of the online communities in general and the expression of identities in particular. In the first step, each unit of analysis was taken as a coding unit to develop five descriptive categories as (a) Sentiments, b) Us vs Them, and finally, c) Key Messages. In the case of some, the units contained multiple coding units (which often occurs in the Web 1.0 OSN with its lengthy and explanatory style of writing), and all of them remained in the dataset as individual coding units.

\section{Thematic analysis}

The Qualitative Content Analysis results showed the associations among the descriptive codes, and we continued with the Thematic Analysis by abstracting the descriptive codes into the interpretive codes to seek more concrete patterns underneath. The final interpretive codes constitute the following three categories - d) Tones of Voice, e) Expected Audience, and f) Identity Manifested.

In this stage, we segmented the unit of analysis into coding units because a unit sometimes contains multiple ideas for different categories. For example, a unit from group B was categorised as "East Asian Women in Germany" under b) Us vs Them category. Still, the context of a unit implies multiple meanings that contribute to the mutual interpretive codes on Thematic Analysis - such as "Stereotyped ethnicity" and "Minority amongst other migrant groups in Germany" under the category f) Identity Manifested (see Table 3).

${ }^{7}$ In Boyatzis's Thematic Analysis (1998), said that at the minimum describes and organizes the repeated observations at maximum interprets aspects of the phenomenon. 
Table 3 Comparative Analysis on Three Online Social Networks

\begin{tabular}{|c|c|c|c|c|}
\hline & & $\begin{array}{l}\text { Web } 1.0 \\
\text { (Website A) }\end{array}$ & $\begin{array}{l}\text { Web } 2.0 \\
\text { (Facebook group B) }\end{array}$ & $\begin{array}{l}\text { Web } 3.0 \\
\text { (Postings on Twitter) }\end{array}$ \\
\hline \multirow[t]{3}{*}{$\begin{array}{l}\text { Descriptive } \\
\text { Codes }\end{array}$} & $\begin{array}{l}\text { a) } \\
\text { Sentiments }\end{array}$ & $\begin{array}{l}\text { 'puzzled', 'confused', } \\
\text { 'sceptic' }\end{array}$ & $\begin{array}{l}\text { 'disgusted', 'frustrated', } \\
\text { 'determined' }\end{array}$ & $\begin{array}{l}\text { 'outrageous', 'weird', } \\
\text { 'perplexed', 'angry' }\end{array}$ \\
\hline & $\begin{array}{l}\text { b) Us vs } \\
\text { Them }\end{array}$ & $\begin{array}{l}\text { Korean-German Migrants vs } \\
\text { Koreans /Japanese }\end{array}$ & $\begin{array}{l}\text { East Asian (Women) in } \\
\text { Germany (or in Europe) vs } \\
\text { Germans in Germany }\end{array}$ & $\begin{array}{l}\text { Ethnic/gender } \\
\text { minorities in foreign } \\
\text { countries vs Racism/ } \\
\text { Sexism }\end{array}$ \\
\hline & $\begin{array}{l}\text { c) Key } \\
\text { messages }\end{array}$ & $\begin{array}{l}\text { - Counter argument against } \\
\text { negative responses to the } \\
\text { ad } \\
\text { - Nothing (little) is wrong } \\
\text { with the ad }\end{array}$ & $\begin{array}{l}\text { - Empowerment of Asian - } \\
\text { Migrants in Europe } \\
\text { - Accusation of the } \\
\text { message of the ad as } \\
\text { stereotyping Asians }\end{array}$ & $\begin{array}{l}\text { - Condemnation of } \\
\text { Racism/Sexism in } \\
\text { Germany (Europe) } \\
\text { - Empowerment of } \\
\text { (East) Asians (women) }\end{array}$ \\
\hline \multirow[t]{3}{*}{$\begin{array}{l}\text { Interpretive } \\
\text { Code }\end{array}$} & $\begin{array}{l}\text { d) Tones } \\
\text { of voice }\end{array}$ & $\begin{array}{l}\text { Mostly calm, barely using } \\
\text { the emotional words or } \\
\text { exclamation mark }\end{array}$ & $\begin{array}{l}\text { Emotional words are often } \\
\text { used, much more in the } 1 \text {, } \\
2 \text { phases, relatively less in } \\
\text { the } 4,5 \text { phases }\end{array}$ & $\begin{array}{l}\text { Highly Emotional, often } \\
\text { with aggressive } \\
\text { expressions and/or } \\
\text { extreme generalisations }\end{array}$ \\
\hline & $\begin{array}{l}\text { e) } \\
\text { Expected } \\
\text { Audience }\end{array}$ & $\begin{array}{l}\text { Korean people living in } \\
\text { Germany, who may } \\
\text { understand both Korean } \\
\text { and German cultural } \\
\text { contexts }\end{array}$ & $\begin{array}{l}\text { People concerning the } \\
\text { issues from Korean- } \\
\text { German relations }\end{array}$ & $\begin{array}{l}\text { - People concerning } \\
\text { the discrimination } \\
\text { issues from all kinds } \\
\text { of subjects in the } \\
\text { world }\end{array}$ \\
\hline & $\begin{array}{l}\text { f) Identity } \\
\text { Manifested }\end{array}$ & $\begin{array}{l}\text { - Traditional Korean } \\
\text { - Antagonism based on the } \\
\text { historical relation with } \\
\text { Japan } \\
\text { - Naturalised Korean- } \\
\text { Germans, having a differ- } \\
\text { ent identity from Koreans } \\
\text { in Korea }\end{array}$ & $\begin{array}{l}\text { - A stereotyped East Asian } \\
\text { - Gender minority } \\
\text { - Minority amongst other } \\
\text { migrants group in } \\
\text { Germany }\end{array}$ & $\begin{array}{l}\text { - (East) Asian } \\
\text { - Gender Minority } \\
\text { - Ethnic Minority } \\
\text { - Humans }\end{array}$ \\
\hline
\end{tabular}

\section{Findings}

To begin with the overarching comparative perspective, the analysis shows that each platform has numerous distinctive characteristics.

First, different audiences of each platform indicate various aspects of implications. Migrants' selection of a platform to manifest specific identity varies, according to the audience given as South Koreans in Germany in the Web 1.0 community (private/ closed), Koreans in Germany and other closely involved people in the Web 2.0 community (semi-private/semi-closed), and finally, worldwide social media users with various nationalities in that of Web 3.0 (public/opened).

Second, the defining "who we are" and "others" are tightly associated with the group identity. Throughout three OSNs, a number of definitions on b) Us vs Them are already the emblem of their identity: for instance, 'Korean in Germany' in the Web 1.0, and 'East Asian' in the Web 2.0 for 'who we are', and 'Japanese' in the Web 1.0, and 'White men' in the Web 3.0 for 'who others are'.

Third, the analysis of sentiments reveals the different bonds of the relationship among the community members, especially in consideration of the degree of emotions expressed in each OSN. On the one hand, the posters in the Web 1.0 seemed to feel the tighter ties with the expected audiences so that the postings keep their tones of voice polite and calm. Unlike some previous positive topics that the members used to share their emotions freely, they tended to talk about such a controversial and disturbing issue more carefully and rationally concerning others' different feelings. It may convince the East Asian culture that people tend to care and concern their friends' feelings 
while expressing their emotions but not to the case with strangers (Ma-Kellams and Blascovich 2012). On the contrary, the postings in Web 3.0 contained the most intense emotional tones of voices because the audience seems not their 'friends' but instant 'partnership' whom the posters could relatively easily attack and end the relationship once the common interest disappears. The members in the Web 3.0 who voluntarily gathered with the same hashtags were not likely to force their identities to others but valued diverse opinions. The most distinguishing dynamic on the sentiment is in the Web 2.0, as its tones of voice have changed throughout those five-time phases (see Fig. 1). The initial postings expressed doubted and uncertain attitudes toward the advertisement, asking other members if their disturbed feelings would be personally oriented. After most of the posters agreed on the interpretation that the advertisement contains ethnic and gender discrimination, the number of postings exploded, and the tone changed to a more explicit emotional expression. When the movement reached the peak phase to initiate the social movement, the postings became much more rational, trying to recruit the people and announcing the progress of their group actions. The postings were changed to a calmer tone of voice in the last phase, but their collective identity became clear and determined - as East Asians in Germany. As such, the sentiments also involves in the distinctive degrees of developing collective identity in each OSN, indicating how community and networks reside differently. The people in the Web 1.0 often indicate their collective identity that the members are valuing the community therein as an actual relationship beyond the screen. However, the web 1.0 has the members relatively tightly knitted and only affiliating themselves with the limited people in the specific circumstance - identifying their community's identity as a Korean heritage but currently belonged to Germany. Therefore, people in web 1.0 do not consider the issue as closely related to them. The web 2.0 created the most firmed solidarity against the discrimination, based on the understanding of transnational identity as East Asians in Germany (Europe). Drawing the more flexible boundaries to include the people from other similar ethnic and geographical backgrounds, the members in the web 2.0 consider 'us' as the broader term that encompasses anyone sharing the same identity. Therefore, the issue was taken more seriously and personally than those in other OSNs. While the movement is moving forward by those organisers in the web 2.0, the members have consolidated the group identity and still uses the space to share the relevant stories and experiences.

In contrast, social networking takes place more instantly and temporally on web 3.0. It provides stronger anonymity and big-data customisation for the members to link those in the same interest easily and filter out those not interested at the same time. This system provides the members great liberty to express their ideas, feelings, and thoughts, but limitations to constitute the proper community due to its basis of a weak tie and temporal interest. Besides, numerous postings in Web 3.0 criticise the advert while highlighting the human rights and justice for the minority people in society overall, but seldom trying to influence or push their opinions to the other people. It indicates that the majority in web 3.0 is in a position taking the universal level of identity as 'human', which, in the end, did not motivate the people to weave strong collective identity with the people who are targeted by the incident, and therefore, harder to form solidarity for the active movements as what Web 2.0 community does. 
Another interesting feature in the analysis is that ethnic discrimination is much more highlighted than other underlying issues in the incident such as sexism. There are many postings in Web 3.0 from different geographical backgrounds that pointed out the gender issue in the commercial. However, most of the postings written by Koreans (or at least written in the language of Korean) on any platforms put their emphasis on the humiliating message of the East Asian cultural heritage, often bringing the clues from the posters' personal experiences that the 'Europeans' are not able to distinguish Chinese, Japanese and Korean people. It sheds lights on how migrants in Germany may concern the perspective of the other people in the destination society, when they shape own new identity.

Finally, the analysis elicits that the identities manifested in each platform differ to each other, in light of transnationalism (see Fig. 2). Identities are labelled considering geographical, cultural, and gender points of view. The group identities examined are as follows with some quotes from each OSN to introduce some examples (translated).

- Web 1.0:

Traditional Korean, who should be distinguished from Japanese because of the hostile historical relation with it: "Why are we Koreans bothered, when the target is obviously a Japanese girl?"

Korean migrants fully integrated in Germany so that different from Koreans in South Korea: "You are still further behind to be integrated, if you don't understand this German joke."

- Web 2.0

East Asian in Germany: "We should speak up to defend East Asians' right in Europe."

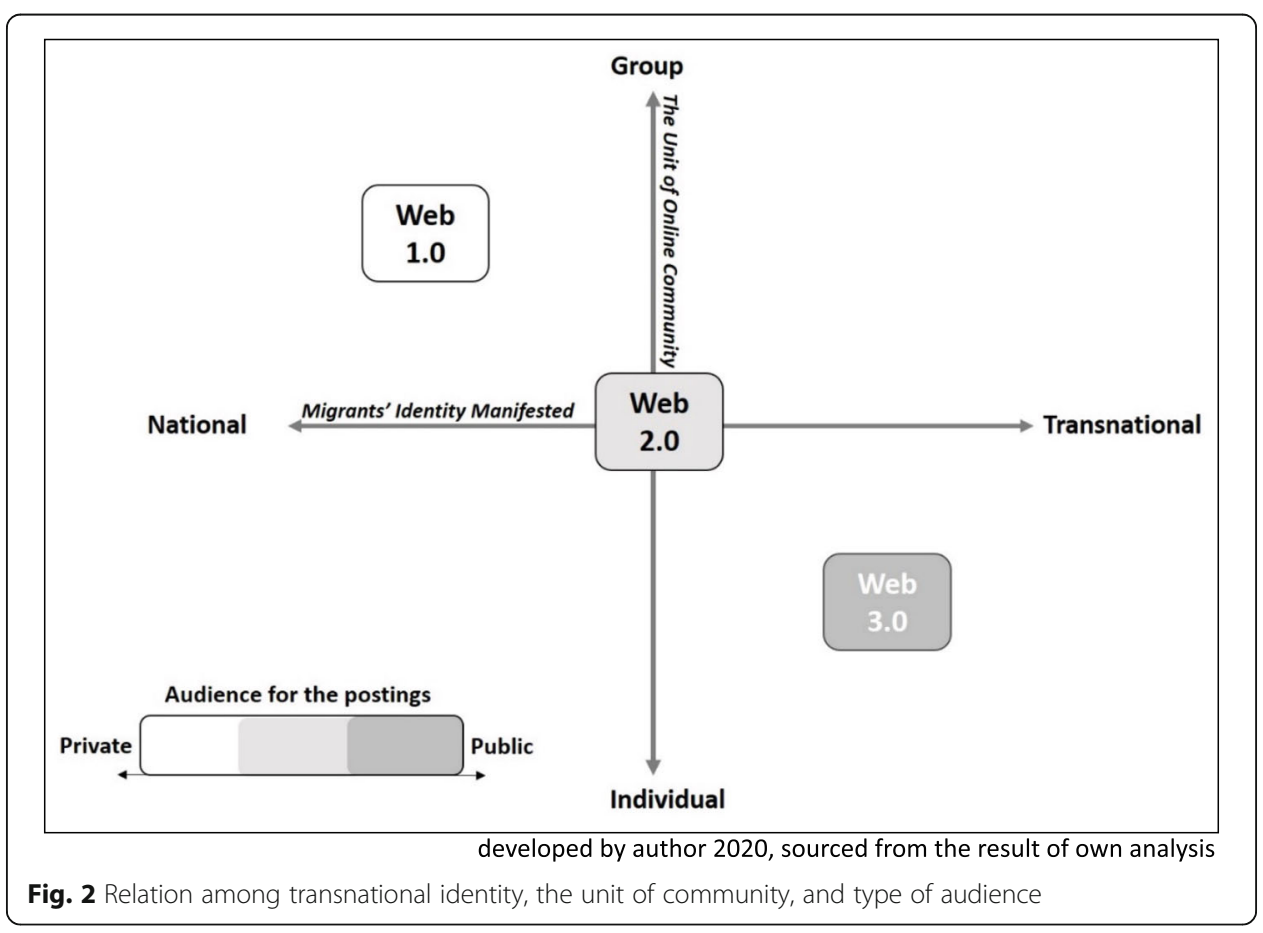


Ethnic and gender minority in Europe: "I am experiencing similar threats and mockeries in my daily life, only because I am (East) Asian woman."

- Web 3.0

Ethnic and Gender Minority: "The ad makes Asian women's everyday life in Germany even harsher."

Women in the white-male-superior society: 'This (ad) reflects white Germans' racial morality about (East) Asian women."

All things taken together, this case study proves that the more advanced type of OSN is used, the more transnational migrants' identity is manifested, associated with the degree of public openness of audiences in each platform. As seen in Fig. 2, migrants are expecting more public audiences in the latter type of OSN than others, considering the definitions of "Us" and "Them" in each community. It can be understood that the more recent type of OSN paves the way for embracing the audience from diverse backgrounds who may have and understand the more transnational identity. Besides, it is evident that the more individual and diversity-valued OSN embraces the more flexible and broader concept of transnational identity.

It is vital to bear in mind that the result does not mean the group identity represents an individual's identity exclusively in a specific OSN. When we look at the Web 2.0 community, the solidarity and the movement had gradually bolstered, and later, there were only remained fewer voices against the leading ideas. Since the third phase started, only the members echoing the developed group identity and participating in the online movement remained and have kept creating relevant postings and replies in the community. It assures again that the people's choice is the result of the negotiation among the type of identity, type of expected audience, and finally, the type of OSN.

The research shows that the OSNs in Web 2.0 and 3.0 show the broader scope of transnational identity, while those in Web 1.0 shows the narrower identity viz. national identity (see also Fig. 2). While transnationalism has flourished in the last decades along with international migration (Portes 2003; Glick-Schiller 2003; Levitt \& Schiller 2004; Castles and Miller 2009; Vertovec 2015; Waldinger 2013; Waldinger 2015, among others), so have the members of migrants' online communities that expended its arena from Web 1.0 to Web 3.0. That means, migrants who wish to share their national identity may feel familiar with the earlier type of online platform, where the migrants' communities form the closed social groups based on the same destination countries.

Such a conventional and heritage-oriented identity in the web 1.0 community may be more common when the Web1.0 platform was emerged and most widely used amongst migrants in the past. Likewise, transnationalism, the more recently disseminated type of identity, is more strongly anchoring in the later types of platforms where the applied technology embraces the worldwide social network. While different generational technologies are co-existing as options for the people to communicate, people tend to choose a technology that may provide a more favourable environment to reflect a specific type of transnational identity. Notably, it is people who continuously keep creating new technology for the better application of the current shape of society, but then, it is technology that enables people to utilise it in a way the technology provides. We reflect these findings vis-à-vis the theories on the relationship between technological evolution and society, and echo the idea that technology and 
people are affecting each other, keep creating the reciprocal relationship. Especially when it comes to the relation between OSNs and migrants' transnational identity, our research shows that the influence does not exist in a single direction, but rather it is the reciprocal relationship.

Given that OSN platforms are existing simultaneously, the technology reflects the period when it was created as a primary mean of social networking. Likewise, our research proves that technology itself does not determine how migrants develop their identity. The research answers back to the existing argument that the online ties hinder migrants from adapting to the new circumstances due to the tighter bond to the society of origin (Komito 2011; Suh and Hsieh 2018, among others).

\section{Conclusion}

Migrants' transnational identity can be diversified by social positioning within and across home and destination society. This paper highlights migrants' dynamic formation of transnational identity and its interaction with OSNs in contemporary society. The comparative case study on three OSNs of Koreans in Germany examines how migrants' transnational identities may differ by their expectations on the audience of each online social network, concerning the technological types of online platform that may encourage or discourage in manifesting own transnational identity, and eventually shaping it as a group identity. The findings also imply the reciprocating relationship between online social networks and the migrants' transnational identity: a certain type of online social network drags a certain type of audience and encourage them to organise such type of community. Likewise, the technological evolution on the online social platform also has been affected by the changing desires of the users, namely migrants in this research, as the more transnational identity migrants wish to share with others, the more audiences who echo such identity are gathered in the more open and transnational type of online platform. From the methodological aspect, the research provides a good example of using qualitative data analysis on the narratives in online social networks as a conduit to understanding the dynamics of international migrants' up-to-date identity and belongings.

All in all, this paper concludes with three core suggestions. First, current online social networks comprising different generational technologies play a significant role in developing migrants' dynamic social values and transnational identities swaying between home and destination society. We should take into account more carefully that a migrant may have different layers of identity that would be selectively manifested in the wide range of online agoras, where expected, a certain audience exists. This means that an individual who has multiple access to various online social networks would choose one of them to share one identity on a specific occasion. Perhaps, choose another network for sharing another identity that could situationally vary from the previous one. Second, the causation between technology and migrants' transnational identities should not be dichotomised as one shapes another. Instead, we suggest that they reciprocally influence and affect each other. People keep creating new technology for the better application of the current shape of society, and that technology enables people to utilise it in a way the technology provides. Finally, migrants' transnational identity, multi-layered and complex, should not be defined by the fixed frames such as conventional nation- 
state or ethnicity concepts but should be contextualised with different social dimensions that may affect the individual's choice of belonging to the host society.

Nota bene, this study only provides the evidence sourced from particular circumstances in the realm of migration society, which leaves generous room for further potential studies. The limitation also lies in observations in the anonymised narratives in the virtual world without knowing those posting writers' personal context. For example, an individual may have a gap between offline and online behaviours regarding the same issue. Or there might be unrevealed reasons for participating/organising such movement other than identity issues. If we could study their deeper reasons of diversifying own identity, it would nurture the vigorous understanding of the relationship between online social networks and the formation of migrants' transnational identity. Accordingly, two tracks of further studies would be suggested, considering the breadth of the study and that of the depth. Widening the breadth of the study is the replicating applications of the two-step Qualitative Data Analysis on the other similar cases with different migrants groups to test whether those cases would be coherent with existing findings. To cope with the depth of this study, the more direct and intimate ways of interaction with corresponding migrants - such as in-depth interview or focus group would be much helpful to see the core mechanism of the current findings, especially when it comes to the relationship between migrants' choice of social communication with others and shaping own unique transnational identity.

\section{Supplementary Information}

The online version contains supplementary material available at https://doi.org/10.1186/s40878-020-00218-w.

Additional file 1: Appendix I. Definitions on each coding unit in two-step Qualitative Data Analysis. Appendix II. Descriptions on Web 1.0, Web 2.0, and Web 3.0.

\section{Abbreviation}

OSN: Online Social Network

\section{Acknowledgements}

As a part of the doctoral dissertation project, we carried out this research with the support from Bamberg Graduate School of Social Science, Otto-Friedrich University Bamberg.

Authors' contributions

SP conducts the case analysis and interprets the results in light of transnationalism. LG contributes to the overall research design and the interpretation in light of evolution of technology and society. The authors read and approved the final manuscript.

Funding

1. This research is the first part of SP'S individual doctoral dissertation project under the PhD programme at Bamberg Graduate School of Social Sciences. Open Access funding enabled and organized by Projekt DEAL.

Availability of data and materials

The codebook that support the findings of this study are available from the corresponding author on reasonable request. The data are not publicly available due to them containing information that could compromise research participant privacy.

Competing interests

There are no competing interests between two authors.

Author details

${ }^{1}$ Bamberg Graduate School of Social Sciences, Otto-Friedrich University Bamberg, Bamberg, Germany. ${ }^{2}$ Institute for Housing and Urban Development Studies, Erasmus University Rotterdam, Rotterdam, Netherlands. 
Received: 8 July 2020 Accepted: 4 December 2020

Published online: 22 March 2021

\section{References}

Aghaei, S. (2012). Evolution of the World Wide Web. From Web 1.0 to Web 4.0. IJWesT, 3(1), 1-10. https://doi.org/10.5121/ ijwest.2012.3101.

Bertelsmann, S. (2018). Factsheet Migration - Skilled worker migration to Germany from third countries 2017. Available online at: https://www.bertelsmann-stiftung.de/fileadmin/files/Projekte/Migration_fair_gestalten/B_Factsheet_Skilled_ Migration_2017.pdf.

Bijker, W. E. (1997). Of bicycles, bakelites, and bulbs. Toward a theory of sociotechnical change. 1. paperback edition. Cambridge, Mass., London: The MIT Press.

Bijker, W. E. (2010). How is technology made? --That is the question! Cambridge Journal of Economics, 34(1), 63-76. https://doi. org/10.1093/cje/bep068.

Blank, G., \& Reisdorf, B. C. (2012). The participatory web. Information, Communication \& Society, 15(4), 537-554. https://doi.org/ $10.1080 / 1369118 X .2012 .665935$

Blommaert, J. (2013). Ethnography, superdiversity and linguistic landscapes: Chronicles of complexity (Vol. 18). Multilingual Matters.

Blommaert, J., \& Varis, P. (2011). Enough is enough: The heuristics of authenticity in superdiversity. Tilburg Papers in Culture Studies, $2,1-13$

Boellstorff, T., Nardi, B., Pearce, C., \& Taylor, T. L. (2012). Ethnography and virtual worlds: A handbook of method. Princeton, New Jersey: Princeton University Press.

Boyatzis, R. E. (1998). In R. E. Boyatzis (Ed.), Transforming qualitative information. Thematic analysis and code development. Thousand Oaks, Calif, London: SAGE Publications.

Boyd, D. M. (1989). Family and personal networks in international migration: recent developments and new agendas. International Migration Review, 23(3), 638-670.

Boyd, D. M., \& Ellison, N. B. (2007). Social Network Sites. Definition, History, and Scholarship. Journal of Computer-Mediated Communication, 13(1), 210-230. https://doi.org/10.1111/j.1083-6101.2007.00393.x.

Caren, N., Andrews, K. T., \& Lu, T. (2020). Contemporary Social Movements in a Hybrid Media Environment. Annual Review of Sociology, 46, 443-465.

Castells, M. (2004). In M. Castells (Ed.), The network society. A cross-cultural perspective. Cheltenham: Edward Elgar.

Castells, M. (2011). Communication power. 1. publ. in paperback. Oxford: Oxford Univ. Press.

Castles, S., \& Miller, M. J. (2009). The age of migration. International population movements in the modern world, (4th ed., ., Rev. \& updated). New York: Guilford Press.

Chen, W., \& Choi, A. S. K. (2011). Internet and social support among Chinese migrants in Singapore. New Media \& Society, 13(7), 1067-1084. https://doi.org/10.1177/1461444810396311.

Cornelius, I., Komito, L., \& Bates, J. (2009). Virtually local. Social media and community among Polish nationals in Dublin. AP, 61(3), 232-244. https://doi.org/10.1108/00012530910959790.

Dekker, R., \& Engbersen, G. (2014). How social media transform migrant networks and facilitate migration. Global Networks, 14(4), 401-418.

Dolata, U. (2013). The transformative capacity of new technologies. A theory of sociotechnical change. London: Routledge (Routledge advances in sociology, 96).

Elo, S., \& Kyngäs, H. (2008). The qualitative content analysis process. Journal of advanced nursing, 62(1), 107-115. https://doi. org/10.1111/j.1365-2648.2007.04569.x

Feenberg, A., \& Bakardjieva, M. (2016). Virtual Community. No 'Killer Implication'. New Media \& Society, 6(1), 37-43. https://doi. org/10.1177/1461444804039904.

Flick, U. (2014). The SAGE handbook of qualitative data analysis. Los Angeles: SAGE.

Fuchs, C. (2008). Internet and society. Social theory in the information age. New York: Routledge (Routledge research in information technology and society, 8). 1. publ.

Gill, N., \& Bialski, P. (2011). New friends in new places: Network formation during the migration process among Poles in the Geoforum, 42(2), 241-249.

Glick-Schiller, N. (2003). The centrality of ethnography in the study of transnational migration: seeing the Wetland instead of the Swamp America arrivals. In American arrivals: Anthropology engages the new immigration (pp. 99-128). School of American Research Press.

Granovetter, M. (1983). The strength of weak ties: A network theory revisited. Sociological theory, (pp. 201-233).

Grzymala-Kazlowska, A. (2016). Social Anchoring: Immigrant Identity, Security and Integration Reconnected? Sociology, 50(6), 1123-1139. https://doi.org/10.1177/0038038515594091.

Hammersley, M. (2015). On ethical principles for social research. International Journal of Social Research Methodology, 18(4), 433-449.

Hammersley, M. \& Atkinson, P. (2007). Ethnography. Principles in Practice.

Hine, C. (2008). Virtual ethnography: Modes, varieties, affordances. In The SAGE handbook of online research methods, (pp. 257-270).

Juris, S. J., Ronayne, M., Shokooh-Valle, F., \& Wengronowitz, J. R. (2012). Negotiating Power and Difference within the 99\%. Social Movement Studies, $11(3-4), 434-440$

Komito, L. (2011). Social media and migration. Virtual community 2.0. Journal of the American Society for Information Science and Technology, 62(6), 1075-1086. https://doi.org/10.1002/asi.21517.

Komito, L., \& Bates, J. (2011). Migrants' information practices and use of social media in Ireland (pp. 289-295). https://doi.org/10 $1145 / 1940761.1940801$.

Levitt, P., \& Schiller, N. G. (2004). Conceptualizing simultaneity: a transnational social field perspective on society 1. International migration review, 38(3), 1002-1039.

Lim, S. S., Bork-Hüffer, T., \& Yeoh, B. S. A. (2016). Mobility, migration and new media. Manoeuvring through physical, digital and liminal spaces. New Media \& Society, 18(10), 2147-2154. https://doi.org/10.1177/1461444816655610.

Lingel, J., Naaman, M., \& Boyd, D. M. (2014). City, self, network: transnational migrants and online identity work (pp. 1502-1510). 
Ma-Kellams, C., \& Blascovich, J. (2012). Enjoying life in the face of death. East-West differences in responses to mortality salience. Journal of Personality and Social Psychology, 103(5), 773-786. https://doi.org/10.1037/a0029366.

Margetts, H., John, P., Hale, S., \& Yasseri, T. (2015). Political turbulence: How social media shape collective action. Princeton, New Jersey: Princeton University Press.

Ministry of Foreign Affairs, Republic of Korea (2019). 재외동포현황보고 [Oversea Koreans Status Report], Seoul, Korea. http:// www.mofa.go.kr/www/brd/m_4080/view.do?seq=369552.

Nedelcu, M. (2012). Migrants' New Transnational Habitus. Rethinking Migration Through a Cosmopolitan Lens in the Digital Age. Journal of Ethnic and Migration Studies, 38(9), 1339-1356. https://doi.org/10.1080/1369183X.2012.698203.

O'Reilly, T. (2007). Web 2.0. Principles and best practices. Sebastopol, Calif:. O'Reilly Media. Available online at http://proquest. safaribooksonline.com/0596527691.

Oiarzabal, P. J. (2013). The Basque diaspora webscape. Identity, nation, and homeland, 1990s-2010s. Reno: Center for Basque Studies University of Nevada Reno (Basque diaspora and migration studies series, No. 7).

Pinch, T. J., \& Bijker, W. E. (1984). The social construction of facts and artefacts: Or how the sociology of science and the sociology of technology might benefit each other. Social studies of science, 14(3), 399-441.

Polletta, F., \& James, J. M. (2001). Collective Identity and Social Movements. Anual Review of Sociology, 27, 283-305 Available online at https:/www.jstor.org/stable/2678623.

Portes, A. (2003). Conclusion: Theoretical Convergencies and Empirical Evidence in the Study of Immigrant Transnationalism. International migration review, 37(3), 874-892.

Postill, J. (2008). Localising the internet beyond communities and networks. New Media \& Society, 10(3), 413-431. https://doi. org/10.1177/1461444808089416.

Pyke, K., \& Dang, T. (2003). "FOB" and "whitewashed": Identity and internalised racism among second generation Asian Americans. Qualitative Sociology, 26(2), 147-172.

Roth-Cohen, O., Ne'eman-Haviv, V., \& Bonny-Noach, H. (2019). \# MeToo Empowerment Through Media: A New Multiple Model for Predicting Attitudes Toward Media Campaigns. International Journal of Communication, 13, 17.

Ryan, L. (2011). Migrants' Social Networks and Weak Ties: Accessing Resources and Constructing Relationships Post-Migration. The Sociological Review, 59(4), 707-724.

Sarangi, S. (1996). Conflation of institutional and cultural stereotyping in Asian migrants' discourse. Discourse \& Society, 7(3), 359-387.

Scheepers, D., Saguy, T., Dovidio, J. F., \& Gaertner, S. L. (2014). A shared dual identity promotes a cardiovascular challenge response during interethnic interactions. Group Processes \& Intergroup Relations, 17(3), 324-341. https://doi.org/10.1177/1368430213517271.

Schreier, M. (2012). Qualitative content analysis in practice. London, the United Kingdom: Sage publications.

Schrooten, M. (2012). Moving ethnography online. Researching Brazilian migrants' online togetherness. Ethnic and Racial Studies, 35(10), 1794-1809. https://doi.org/10.1080/01419870.2012.659271.

Sheringham, O. (2010). Creating' Alternative Geographies'. Religion, Transnationalism and Everyday Life. Geography Compass, 4(11), 1678-1694. https://doi.org/10.1111/j.1749-8198.2010.00393.x.

Sismondo, S. (2004). An introduction to science and technology studies. 1. publ. Malden, MA: Blackwell.

Sonn, C. C., \& Fisher, A. T. (1996). Psychological sense of community in a politically constructed group. Journal of Community Psychology, 24(4), 417-430.

Suh, M., \& Hsieh, G. (2018). The "Had Mores". Exploring korean immigrants' information behavior and ICT usage when settling in the United States. Journal of the Association for Information Science and Technology, 70(1), 38-48. https://doi.org/10.1002/asi.24078.

Tamaki, E. (2011). Transnational Home Engagement among Latino and Asian Americans. Resources and Motivation. International Migration Review, 45(1), 148-173. https://doi.org/10.1111/j.1747-7379.2010.00842.x.

Vertovec, S. (2007). Super-diversity and its implications. Ethnic and Racial Studies, 30(6), 1024-1054.

Vertovec, S. (2009). Transnationalism. Oxon: Routledge.

Vertovec, S. (2015). In S. Vertovec (Ed.), Diversities old and new. Migration and socio-spatial patterns in New York, Singapore and Johannesburg (2015th ed.). Basingstoke, Hampshire: Palgrave Macmillan (Global diversities).

Vickery, G., \& Wunsch-Vincent, S. (2007). In S. Wunsch-Vincent, \& G. Vickery (Eds.), Participative web and user-created content. Web 2.0, wikis and social networking. Paris: Organisation for Economic Co-operation and Development.

Vieten, U. M. (2014). When I Land in Islamabad I Feel Home and When I Land in Heathrow I Feel Home. In Migration, Diaspora and Identity (pp. 51-74). Dordrecht: Springer.

Waldinger, R. (2013). Immigrant transnationalism. Current Sociology, 61(5-6), 756-777.

Waldinger, R. D. (2015). The cross-border connection. Immigrants emigrants and their homelands. Cambridge: Harvard Univ. Press Available online at http://www.degruyter.com/view/product/430598.

Wellman, B. (2001). Physical Place and Cyber Place. The Rise of Networked Individualism. International Journal of Urban and Regional Research, 25(2), 227-252

Wellman, B. (2005). Community: from neighborhood to network. Communications of the ACM, 48(10), 53-55.

Yearley, S. (2014). Science, Technology, and Social Change (Routledge Revivals).

\section{Publisher's Note}

Springer Nature remains neutral with regard to jurisdictional claims in published maps and institutional affiliations. 